\title{
Advanced ceramics: Combustion synthesis and properties
}

\author{
K C PATIL \\ Department of Inorganic and Physical Chemistry, Indian Institute of Science, Bangalore \\ 560012, India
}

\begin{abstract}
Fine-particle ceramic powders such as chromites, manganites, ferrites, cobaltites, aluminas $\left(\alpha-\mathrm{Al}_{2} \mathrm{O}_{3}, \mathrm{Cr}^{3+} / \mathrm{Al}_{2} \mathrm{O}_{3}\right.$, zirconia-toughened alumina, mullite and cordierite), ceria, titania, zirconia ( $t, m, c$ and PSZ), dielectric oxides $\left(\mathrm{MTiO}_{3}, \mathrm{PZT}\right.$ and PLZT) as well as high $T_{c}$ cuprates have been prepared by the combustion of redox compounds or mixtures. The combustion-derived oxide materials are of submicron size with a large surface area and are sinteractive.
\end{abstract}

Keywords. Combustion synthesis; metal oxides; ceramics.

\section{Introduction}

Traditionally, the word ceramics is associated with clay-based products such as bricks, tiles, pottery, table ware, sanitary ware and glass. Naturally occurring minerals like sand, quartz, bauxite, feldspar etc are used in the manufacture of these materials. Advanced ceramics differ from conventional ceramics in their high-mechanical strength, fracture toughness, wear resistance, refractory, dielectric, magnetic and optical properties. Advanced ceramics or fine ceramics are high value-added inorganic materials produced from high purity synthetic powders to control microstructure and properties. Wet-chemical routes (Segal 1989) e.g. coprecipitation, sol-gel, spraydry, freeze-dry etc are usually employed to prepare advanced ceramic powders having submicron size, narrow size distribution and absence of particle agglomerates. However, these methods are quite involved, require long processing time, costly chemicals and special equipment. Therefore, there is a need for an alternative to the wet-chemical methods.

\section{Combustion synthesis}

Many researchers have attempted to use the heat generated by exothermic chemical reactions in the synthesis of high-temperature ceramic materials. Aluminothermite process,

$$
\mathrm{Fe}_{2} \mathrm{O}_{3}+2 \mathrm{Al} \rightarrow \mathrm{Al}_{2} \mathrm{O}_{3}+2 \mathrm{Fe},
$$

pioneered by Goldschmidt (1898) was used to prepare metals and alloys (Carlson 1973). Walton and Poulos (1959) synthesized a number of refractory cermets: oxideboride, oxide-carbide and oxide-silicide. More recently, Merzhanov used the exothermic reaction between the elements (metal-fuel and nonmetal-oxidizer) to produce a host of materials: borides, carbides, carbonitrides, cermets, chalcogenides, hydrides, nitrides, oxides and silicides (Merzhanov 1993). This process, popularly known as self-propagating high-temperature synthesis (SHS), is also called furnaceless or fire synthesis. 
Here, we present the results of a modified combustion process (low temperature initiated, self-propagating, gas-producing, exothermic reaction) for the synthesis of ceramics employing redox compounds and mixtures. The term combustion covers smouldering (heterogeneous) flaming (homogeneous gas phase) as well as explosive reactions. The rate of combustion determines the nature of reaction i.e. decomposition, deflagration or detonation. Synthesis of ceramic oxides is achieved by smouldering and flaming reactions.

\subsection{Preparation of oxides by the combustion of redox compounds}

Hydrazine and its derivatives (mono methyl, unsymmetric disubstituted methyl hydrazines and hydrazides) are well-known energetic rocket fuels. Hydrazine being a endothermic compound $\left(\Delta H_{f}=+12 \mathrm{kcal} \mathrm{mol}^{-1}\right)$ could explode if not properly handled or controlled. The strategy for using hydrazine and its derivatives as fuels for combustion synthesis of ceramic oxides involves complexation with appropriate metal ions. Thus, the explosivity of metal hydrazines, $\mathrm{M}\left(\mathrm{N}_{2} \mathrm{H}_{4}\right)^{2+}$ containing oxidizing anions like nitrate and perchlorate could be controlled by replacing the oxidizing anions in the complex by reducing groups like formate, acetate and oxalate. These complexes have low ignition temperature $\left(<300^{\circ} \mathrm{C}\right)$ and once ignited decompose autocatalytically to yield fine particle oxides. Mixed oxides like ferrites and cobaltites have been prepared by the combustion of these metal hydrazine precursors (Patil 1986, 1991).

Hydrazine has a great affinity for carbondioxide and forms hydrazine carboxylic acid, $\mathrm{N}_{2} \mathrm{H}_{3} \mathrm{COOH}$. Hydrazine carboxylate anion, $\mathrm{N}_{2} \mathrm{H}_{3} \mathrm{COO}^{-}$, is a bidentate ligand and forms a variety of crystalline complexes with metal ions, e.g. $\mathrm{M}\left(\mathrm{N}_{2} \mathrm{H}_{3} \mathrm{COO}\right)_{2}$, $\mathrm{M}\left(\mathrm{N}_{2} \mathrm{H}_{3} \mathrm{COO}\right)_{2} \cdot \mathrm{XH}_{2} \mathrm{O}, \mathrm{M}\left(\mathrm{N}_{2} \mathrm{H}_{3} \mathrm{COO}\right)_{2}\left(\mathrm{~N}_{2} \mathrm{H}_{4}\right)_{2}$ and $\mathrm{N}_{2} \mathrm{H}_{5} \mathrm{M}\left(\mathrm{N}_{2} \mathrm{H}_{3} \mathrm{COO}\right)_{3} \cdot \mathrm{H}_{2} \mathrm{O}$ where $\mathrm{M}=\mathrm{Mg}, \mathrm{Ca}, \mathrm{Cr}, \mathrm{Mn}, \mathrm{Fe}, \mathrm{Co}, \mathrm{Ni}, \mathrm{Cu}$ or $\mathrm{Zn}$. These complexes and their solid solutions have low ignition temperatures $\left(120-300^{\circ} \mathrm{C}\right)$ and decompose/combust in the presence of air autocatalytically with the evolution of $\mathrm{NH}_{3}, \mathrm{H}_{2} \mathrm{O}$ and $\mathrm{CO}_{2}$ to yield fine particle oxides. A large number of technologically important oxide materials have been prepared by the combustion of these redox compounds. These include $\gamma-\mathrm{Fe}_{2} \mathrm{O}_{3}$ (Ravindranathan and Patil 1986), cobalt doped $\gamma-\mathrm{Fe}_{2} \mathrm{O}_{3}$ (Suresh et al 1989a), $\mathrm{CeO}_{2}$ (Mahesh et al 1986) and mixed metal oxides like cobaltites, $\mathrm{MCo}_{2} \mathrm{O}_{4}$ (Ravindranathan et al 1987a), ferrites, $\mathrm{MFe}_{2} \mathrm{O}_{4}$ (Ravindranathan and Patil 1987b), Ni-Zn ferrites (Ravindranathan and Patil 1987c; Suresh and Patil 1992), Mn-Zn ferrites (Suresh et al 1989b), Mg-Zn ferrites (Manoharan and Patil 1989), manganites, $\mathrm{MMn}_{2} \mathrm{O}_{4}$ (Arul Dhas and Patil 1993a) and $\mathrm{ZrO}_{2}, \mathrm{TiO}_{2}$ and $\mathrm{ZrTiO}_{4}$ (Sekar and Patil 1993). Fine particle properties like specific surface area and average agglomerated particle size (Stokes diameter) of the simple and mixed metal oxides prepared by the combustion of hydrazine carboxylate precursors are summarized in table 1 . The surface area values of the metal oxide powders are in the range of $4-140 \mathrm{~m}^{2} / \mathrm{g}$, which is much larger than those obtained by the conventional ceramic method. The combustion-derived powders have narrow size distribution with average agglomerate particle sizes being in the range of $0.5-5 \mu \mathrm{m}$. The fine particle nature of the combustion-derived powders is attributed to the low exothermicity of the combustion reaction and evolution of large amount of gases $\left(\mathrm{NH}_{3}, \mathrm{H}_{2} \mathrm{O}, \mathrm{CO}_{2}\right)$ which help to dissipate the heat thereby preventing the oxides from sintering. 
Table 1. Properties of oxide materials prepared by the combustion of redox compounds.

\begin{tabular}{|c|c|c|c|}
\hline Redox compound & Product & $\begin{array}{c}\text { Surface } \\
\text { area }\left(\mathrm{m}^{2} / \mathrm{g}\right)\end{array}$ & $\begin{array}{l}\text { Av. aggl. } \\
\text { size }(\mu \mathrm{m})\end{array}$ \\
\hline $\mathbf{M}(\mathrm{hc})_{2}$ & $\mathrm{MO}, \mathrm{M}_{2} \mathrm{O}_{3}(\mathrm{M}=\mathrm{Mg}, \mathrm{Mn} \text { to } \mathrm{Zn})^{\dagger}$ & - & - \\
\hline $\mathrm{M}(\mathrm{hc})_{2} \cdot 2 \mathrm{H}_{2} \mathrm{O}$ & $\mathrm{MO}, \mathrm{M}_{2} \mathrm{O}_{3}(\mathrm{M}=\mathrm{Mg}, \mathrm{Mn} \text { to } \mathrm{Zn})^{\dagger}$ & - & - \\
\hline $\mathrm{Ln}(\mathrm{hc})_{3} \cdot 3 \mathrm{H}_{2} \mathrm{O}$ & $\mathrm{Ln}_{2} \mathrm{O}_{3}(\mathrm{Ln}=$ rare earths $), \mathrm{CeO}_{2}$ & 90 & 0.76 \\
\hline $\mathrm{MO}(\mathrm{hc})_{2} \cdot 2 \mathrm{H}_{2} \mathrm{O}$ & $\mathrm{MO}_{2}(\mathrm{M}=\mathrm{T} 1$ and $\mathrm{Zr}$ and their ss $)$ & $13-114$ & $0.8-1 \cdot 6$ \\
\hline $\mathrm{M}(\mathrm{hc})_{2}\left(\mathrm{~N}_{2} \mathrm{H}_{4}\right)_{2}$ & $\mathrm{MO}, \mathrm{M}_{2} \mathrm{O}_{3}(\mathrm{M}=\mathrm{Mg}, \mathrm{Mn} \text { to } \mathrm{Zn})^{\dagger}$ & $7-34$ & $2-5$ \\
\hline $\mathrm{N}_{2} \mathrm{H}_{5} \mathrm{M}(\mathrm{hc})_{3} \cdot \mathrm{H}_{2} \mathrm{O}$ & $\mathrm{MO}, \mathrm{M}_{2} \mathrm{O}_{3}(\mathrm{M}=\mathrm{Mg}, \mathrm{Mn} \text { to } \mathrm{Zn})^{\dagger}$ & $18-75$ & $2-5$ \\
\hline$\left(\mathrm{N}_{2} \mathrm{H}_{5}\right) \mathrm{M}_{1 / 3} \mathrm{Fe}_{2 / 3}(\mathrm{hc})_{3} \cdot \mathrm{H}_{2} \mathrm{O}$ & $\mathrm{MFe}_{2} \mathrm{O}_{4}(\mathrm{M}=\mathrm{Mg}, \mathrm{Mn}$, Co to $\mathrm{Zn})$ & $26-140$ & $1-5$ \\
\hline $\mathrm{N}_{2} \mathrm{H}_{5} \mathrm{M}_{x} \mathrm{Zn}_{1-x} \mathrm{Fe}_{2}(\mathrm{hc})_{3} \cdot 3 \mathrm{H}_{2} \mathrm{O}$ & $\mathrm{M}_{x} \mathrm{Zn}_{1-x} \mathrm{Fe}_{2} \mathrm{O}_{4}(\mathrm{M}=\mathrm{Mg}, \mathrm{Mn}$ and $\mathrm{Ni})$ & $4-140$ & $1-5$ \\
\hline$\left(\mathrm{N}_{2} \mathrm{H}_{5}\right) \mathrm{M}_{1 / 3} \mathrm{Co}_{2 / 3}(\mathrm{hc})_{3} \cdot \mathrm{H}_{2} \mathrm{O}$ & $\mathrm{MCo}_{2} \mathrm{O}_{4}(\mathrm{M}=\mathrm{Mg}, \mathrm{Mn}$, Co to $\mathrm{Zn})$ & $12-116$ & $0 \cdot 8-4 \cdot 2$ \\
\hline$\left(\mathrm{N}_{2} \mathrm{H}_{5}\right) \mathrm{M}_{1 / 3} \mathrm{Mn}_{2 / 3}(\mathrm{hc})_{3} \cdot \mathrm{H}_{2} \mathrm{O}$ & $\mathrm{MMn}_{2} \mathrm{O}_{4}(\mathrm{M}=\mathrm{Co}$ and $\mathrm{Ni})$ & $20-76$ & $0.7-5$ \\
\hline $\mathrm{M}_{1 / 3} \mathrm{Mn}_{2 / 3}\left(\mathrm{hc}_{2} \cdot 2 \mathrm{H}_{2} \mathrm{O}\right.$ & $\mathrm{MMn}_{2} \mathrm{O}_{4}(\mathrm{M}=\mathrm{Mg}$ and $\mathrm{Zn})$ & $27-60$ & $1 \cdot 9-5$ \\
\hline $\mathrm{PbMO}(\mathrm{OH})_{2}(\mathrm{hc})_{2} \cdot \mathrm{H}_{2} \mathrm{O}$ & $\mathrm{PbMO}_{3}(\mathrm{M}=\mathrm{Ti}$ and $\mathrm{Zr}$ and their ss $)$ & $20-43$ & $0.5-1$ \\
\hline
\end{tabular}

Note hc $=\mathrm{N}_{2} \mathrm{H}_{3} \mathrm{COO}$, ss $=$ solid solution, ${ }^{\dagger} \mathrm{Fe}_{2} \mathrm{O}_{3}$ forms $\gamma$-phase.

Although the preparation of fine particle oxides by the combustion of redox compounds is quite simple and attractive, it has certain limitations. First, it takes several days to prepare the metal hydrazine carboxylate precursors. Secondly, the yield of the oxide is only $\simeq 20 \%$. Finally, not all metals form hydrazine carboxylate complexes and therefore it was not possible to prepare other oxides like aluminas and chromites which are formed at fairly high temperatures $\left(>1000^{\circ} \mathrm{C}\right)$. This has been achieved by using flaming reactions employing metal nitrates and energetic fuels like urea and hydrazides.

\subsection{Preparation of oxides by the combustion of redox mixtures}

Redox mixtures like $\mathrm{KNO}_{3}+\mathrm{C}+\mathrm{S}$ (gun powder) once ignited undergo self-propagating, gas-producing exothermic decomposition. Similar exothermic reactions of redox mixtures are used in rocket propellants e.g. $\mathrm{NH}_{4} \mathrm{ClO}_{4}-\mathrm{Al}-\mathrm{CTPB}$. These redox mixtures containing metallic ingredients $(\mathrm{Mg}, \mathrm{Al})$ are known to give metal oxides as undesired products of combustion. This phenomenon has now been exploited to actually synthesize metal oxides by the combustion of stoichiometric mixtures of metal nitrates (oxidizer) and urea/hydrazine-based fuels.

The stoichiometric composition of the metal nitrate (oxidizer) and fuel redox mixtures was calculated based on the total oxidizing and reducing valency of the oxidizer and the fuel which serve as a numerical coefficient for stoichiometric balance such that the equivalence ratio, $\Phi_{e}$ is unity, i.e. $\mathrm{O} / \mathrm{F}=1$ and the energy released is maximum (Jain et al 1981). In propellant chemistry, the species $\mathrm{M}^{2+}, \mathrm{M}^{3+}, \mathrm{M}^{4+}, \mathrm{C}$ and $\mathrm{H}$ are considered to be reducing with corresponding valencies $+2,+3,+4,+4$ and +1 . Elemental oxygen is considered to be an oxidizing species with valency -2 . The valency of nitrogen is considered to be zero. According to this oxidizing and reducing valencies of the fuels such as urea $\left(\mathrm{CH}_{4} \mathrm{~N}_{2} \mathrm{O}, \mathrm{U}\right)$, carbohydrazide $\left(\mathrm{CH}_{6} \mathrm{~N}_{4} \mathrm{O}, \mathrm{CH}\right)$, tetra formyl tris-azine $\left(\mathrm{C}_{4} \mathrm{H}_{16} \mathrm{~N}_{6} \mathrm{O}_{2}\right.$, TFTA), oxalyl dihydrazide $\left(\mathrm{C}_{2} \mathrm{H}_{6} \mathrm{~N}_{4} \mathrm{O}_{2}, \mathrm{ODH}\right)$, maleic hydrazide $\left(\mathrm{C}_{4} \mathrm{H}_{4} \mathrm{~N}_{2} \mathrm{O}_{2}, \mathrm{MH}\right)$, and malonic dihydrazide $\left(\mathrm{C}_{3} \mathrm{H}_{8} \mathrm{~N}_{4} \mathrm{O}_{2}, \mathrm{MDH}\right)$ are $+6,+8,+28,+10,+16$, and +16 respectively. 
2.2a Preparation of oxides: Stoichiometric amount of metal nitrate (oxidizer) and fuel when ignited $\simeq 350-500^{\circ} \mathrm{C}$ undergo self-propagating, gas-producing combustion reaction (smouldering or flaming) (temp. $900-1500^{\circ} \mathrm{C}$ ) to yield voluminous metal oxide in less than $5 \mathrm{~min}$. The high in situ temperature $\left(\simeq 1500^{\circ} \mathrm{C}\right)$ attained during the combustion synthesis of $\alpha-\mathrm{Al}_{2} \mathrm{O}_{3}$ using $\mathrm{Al}\left(\mathrm{NO}_{3}\right)_{3}$-urea mixture has been attributed to the gas phase reaction of combustible decomposition products of urea $(\mathrm{CO}, \mathrm{HNCO}$, $\mathrm{NH}_{3}$ ) and the aluminium nitrate (nitrogen oxides). A number of advanced ceramic oxide materials (table 2) have been prepared by the combustion of metal nitrateurea/hydrazide fuels. These include: (i) refractory oxides such as $\alpha$-alumina (Kingsley and Patil 1988), ruby (Kingsley et al 1988, 1990a), metal aluminates (Kingsley et al 1990b), othoaluminates and aluminium garnet (Kingsley et al 1990c), ceria (Sekar et al 1990), zirconia (Arul Dhas and Patil 1992), pyrochlore zirconates (Arul Dhas and Patil 1993b), metal chromites (Manoharan et al 1990, 1992a; Gopichandran and Patil 1992a); (ii) low-thermal expansion coefficient materials like mullite (Gopichandran and Patil 1990), cordierite (Gopichandran and Patil 1993); (iii) toughened ceramics such as partially stabilized zirconia (PSZ) (Arul Dhas and Patil 1992), zirconiaalumina composites (Kingsley and Patil 1990d; Arul Dhas and Patil 1993c); (iv) magnetic materials like $\gamma-\mathrm{Fe}_{2} \mathrm{O}_{3}$ (Suresh and Patil 1993), spinel ferrites, othoferrites and iron garnet (Suresh et al 1991); (v) dielectric oxides such as $\mathrm{MTiO}_{3}, \mathrm{MZrO}_{3}, \mathrm{PZT}$, PLZT (Sekar et al 1992a, b); (vi) high $T_{c}$ cuprates $\mathrm{La}_{2-x} \mathrm{Sr}_{x} \mathrm{CuO}_{4}$ (Manoharan et al 1992b; Gopichandran and Patil 1992b) and (vii) miscellaneous oxides like spinel manganites (Arul Dhas and Patil 1993a), perovskite manganites and nickelates (Manoharan and Patil 1993).

The particulate properties such as surface area and particle size of oxide materials prepared by the combustion of redox mixtures are summarized in table 2 . The surface

Table 2. Properties of oxides prepared by the combustion of redox mixtures.

\begin{tabular}{|c|c|c|}
\hline Oxides & $\begin{array}{l}\text { Surface area } \\
\left(\mathrm{m}^{2} / \mathrm{g}\right)\end{array}$ & $\begin{array}{l}\text { Av. aggl. size } \\
(\mu \mathrm{m})\end{array}$ \\
\hline$\alpha-\mathrm{Al}_{2} \mathrm{O}_{3}$ & $8(U)$ & 4 \\
\hline $\mathrm{MAl}_{2} \mathrm{O}_{4}(\mathrm{M}=\mathrm{Mg}, \mathrm{Co}, \mathrm{Ni}, \mathrm{Cu}$ and $\mathrm{Zn})$ & $1-85(\mathrm{U}, \mathrm{CH})$ & $1-6$ \\
\hline$t-\mathrm{ZrO}_{2} / \mathrm{Al}_{2} \mathrm{O}_{3}$ & $3-65(\mathrm{U}, \mathrm{CH})$ & $3-5$ \\
\hline $3 \mathrm{Al}_{2} \mathrm{O}_{3} \cdot 2 \mathrm{SiO}_{2}$ (mullite) & $12-45(U)$ & 4-8 \\
\hline $\mathrm{Mg}_{2} \mathrm{Al}_{4} \mathrm{Si}_{5} \mathrm{O}_{18}$ (cordierite) & 45-135 (U) & $10-15$ \\
\hline $\mathrm{Y}_{3} \mathrm{Al}_{5} \mathrm{O}_{12}$ & $3-7(\mathrm{U})$ & $2-5$ \\
\hline $\mathrm{MCr}_{2} \mathrm{C}_{4}(\mathrm{M}=\mathrm{Mg}, \mathrm{Fe}, \mathrm{Co}, \mathrm{Ni}, \mathrm{Cu}$ and $\mathrm{Zn})$ & 13-70 (U, TFTA) & $0.5-2$ \\
\hline $\mathrm{LnCrO}_{3}(\mathrm{Ln}=\mathrm{La}, \mathrm{Pr}, \mathrm{Nd}, \mathrm{Sm}, \mathrm{Gd}, \mathrm{Dy}$ and $\mathrm{Y})$ & 6-35 (TFTA) & $0.4-5$ \\
\hline $\mathrm{LnFeO}_{3}(\mathrm{Ln}=\mathrm{La}, \mathrm{Pr}, \mathrm{Nd}, \mathrm{Sm}, \mathrm{Gd}, \mathrm{Dy}$ and $\mathrm{Y})$ & 4-90 (ODH, 'TFTA) & \\
\hline $\mathrm{MFe}_{2} \mathrm{O}_{4}(\mathrm{M}=\mathrm{Mg}, \mathrm{Fe}, \mathrm{Co}, \mathrm{Ni}, \mathrm{Cu}$ and $\mathrm{Zn})$ & $20-100($ ODH, TFTA $)$ & $2-8$ \\
\hline $\mathrm{La}_{2}(\mathrm{Sr}) \mathrm{CuO}_{4}$ & 3-5 (TFTA, MH) & $0.6-3$ \\
\hline $\mathrm{Y}_{3} \mathrm{Fe}_{5} \mathrm{O}_{12}$ & $10-90(\mathrm{ODH})$ & $1-5$ \\
\hline$\gamma-\mathrm{Fe}_{2} \mathrm{O}_{3}$ & 45(MDH) & $1 \cdot 78$ \\
\hline $\mathrm{ZrO}_{2}, \mathrm{PSZ}$ & 3-13 (CH) & $0.8-2.5$ \\
\hline $\mathrm{Ln}_{2} \mathrm{Zr}_{2} \mathrm{O}_{7}(\mathrm{Ln}=\mathrm{La}$ to $\mathrm{Dy})$ & $4-20(\mathrm{CH}, \mathrm{U})$ & $0 \cdot 4-4$ \\
\hline $\mathrm{MTiO}_{3}(\mathrm{Ca}, \mathrm{Sr}, \mathrm{Ba}$ and $\mathrm{Pb})$ & 4-30 (TFTA, ODH) & $0.7-1 \cdot 15$ \\
\hline $\mathrm{CeO}_{2}$ & 14-90 (U, TFTA, CH, ODH) & $0 \cdot 6-1 \cdot 7$ \\
\hline $\mathrm{MMn}_{2} \mathrm{O}_{4}(\mathrm{M}=\mathrm{Mg}, \mathrm{Co}, \mathrm{Ni}, \mathrm{Cu}$ and $\mathrm{Zn})$ & $30-60(\mathrm{MH})$ & $0 \cdot 6-1$ \\
\hline
\end{tabular}

${ }^{\dagger}$ Fuels used for the combustion are indicated in the parentheses. 
Table 3. Comparison of properties of oxides prepared by the combustion of redox compounds (A) and redox mixtures (B).

\begin{tabular}{|c|c|c|c|c|}
\hline \multirow[b]{3}{*}{ Oxide } & \multicolumn{4}{|c|}{ Properties } \\
\hline & \multicolumn{2}{|c|}{ Surface area $\left(\mathrm{m}^{2} / \mathrm{g}\right)$} & \multicolumn{2}{|c|}{ Particle size $(\mu \mathrm{m})$} \\
\hline & A & B & A & B \\
\hline $\mathrm{CeO}_{2}$ & 90 & $14-90$ & $0 \cdot 76$ & $0 \cdot 6-1 \cdot 7$ \\
\hline$\gamma-\mathrm{Fe}_{2} \mathrm{O}_{3}$ & 75 & 45 & $2 \cdot 54$ & 1.78 \\
\hline $\mathrm{MFe}_{2} \mathrm{O}_{4}(\mathrm{M}=\mathrm{Mg}, \mathrm{Mn}$ to $\mathrm{Zn})$ & $26-140$ & $20-100$ & $1-5$ & $2-8$ \\
\hline $\mathrm{Ni}_{1-x} \mathrm{Zn}_{x} \mathrm{Fe}_{2} \mathrm{O}_{4}$ & $48-108$ & $85-95$ & $1-5$ & $1-5$ \\
\hline $\mathrm{MCO}_{2} \mathrm{O}_{4}(\mathrm{M}=\mathrm{Mg}, \mathrm{Mn}$ to $\mathrm{Zn})$ & $12-116$ & $1-45$ & $0 \cdot 8-4 \cdot 2$ & $0.5-3$ \\
\hline $\mathrm{MMn}_{2} \mathrm{O}_{4}(\mathrm{M}=\mathrm{Mg}$, Co to $\mathrm{Zn})$ & $20-76$ & $30-60$ & $0.7-5$ & $0 \cdot 6-1$ \\
\hline $\mathrm{MTiO}_{3}(\mathrm{M}=\mathrm{Ca}, \mathrm{Sr}, \mathrm{Ba}$ and $\mathrm{Pb})$ & $18-42$ & $19-30$ & $0.47-0.54$ & $0.7-0.9$ \\
\hline PZT & $20-43$ & $19-30$ & $0 \cdot 5-1$ & $0 \cdot 7-1 \cdot 1$ \\
\hline PLZT & 29 & 30 & 0.52 & 0.53 \\
\hline
\end{tabular}

area values of the metal oxide powders prepared by the combustion of redox mixture are in the range of $2-135 \mathrm{~m}^{2} / \mathrm{g}$. The average agglomerate particle sizes of these powders are in the range of $0.6-15 \mu \mathrm{m}$.

2.3 Comparison of properties of oxides prepared by the combustion of redox compounds and mixtures

Only few oxides could be prepared by both the processes. These include, cobaltites, ferrites and dielectrics $\left(\mathrm{PbZr}_{0.53} \mathrm{Ti}_{0.47} \mathrm{O}_{3}, \mathrm{PZT}\right.$ etc.) which are formed at low temperature $\left(<1000^{\circ} \mathrm{C}\right)$. A comparative account of properties of oxides prepared by both combustion processes is given in table 3 . It can be seen that the surface area of the oxide powders prepared by the combustion of redox compounds are higher than those obtained by the combustion of redox mixtures. This is because redox compounds undergo flameless (smouldering) combustion whereas redox mixture burns with a flame. Consequently, the average agglomerate particle size (light scattering sedimentation method) of the oxide powders prepared by the combustion of redox mixtures is lower than that of oxide powders obtained by the combustion of redox compounds. The marked difference in surface area and particle size in both the processes can be explained by the amount of gaseous products that are evolved during combustion. For example, the combustion synthesis of $\gamma-\mathrm{Fe}_{2} \mathrm{O}_{3}$ by both the methods can be represented as:

$$
\begin{aligned}
& 2\left(\mathrm{~N}_{2} \mathrm{H}_{5}\right) \mathrm{Fe}\left(\mathrm{N}_{2} \mathrm{H}_{3} \mathrm{COO}\right)_{3} \cdot \mathrm{H}_{2} \mathrm{O} \underset{<200^{\circ} \mathrm{C}}{\stackrel{\text { air }}{\longrightarrow}} \mathrm{Fe}_{2(\mathrm{~g})}+16 \mathrm{O}_{2} \mathrm{O}_{(\mathrm{g})}+6 \mathrm{CO}_{2(\mathrm{~g})}+ \\
& \text { (30 mol of gases } / \mathrm{Fe}_{2} \mathrm{O}_{3} \text { ) } \\
& 16 \mathrm{Fe}\left(\mathrm{NO}_{3}\right)_{3}+15 \mathrm{C}_{3} \mathrm{H}_{8} \mathrm{~N}_{4} \mathrm{O}_{2} \underset{350^{\circ} \mathrm{C}}{\longrightarrow} 8 \mathrm{Fe}_{2} \mathrm{O}_{3(\mathrm{~s})}+45 \mathrm{CO}_{2(\mathrm{~g})}+ \\
& \text { (MDH) } \quad 350^{\circ} \mathrm{C} 54 \mathrm{~N}_{2(\mathrm{~g})}+60 \mathrm{H}_{2} \mathrm{O}_{(\mathrm{g})} \\
& \text { (20 mol of gases/Fe } \mathrm{Fe}_{2} \mathrm{O}_{3} \text { ). }
\end{aligned}
$$


The combustion of redox compound (equation (1)) liberates 30 moles of gaseous products whereas redox mixture gives only 20 moles (equation (2)). It is interesting to note that combustion of redox compound yields low temperature phase $\left(\gamma-\mathrm{Fe}_{2} \mathrm{O}_{3}\right)$, whereas combustion of redox mixture gives usually a high temperature phase $\left(\alpha-\mathrm{Al}_{2} \mathrm{O}_{3}\right.$, $\alpha-\mathrm{Fe}_{2} \mathrm{O}_{3}$ etc). However by changing the fuel one could alter the energetics of the redox mixture and prepare various metastable phases.

\section{Sintering and microstructure}

Sintering behaviour of the combustion derived powders was studied by crushing the as-synthesized powders in an agate mortar and pelletizing under 20-70 MPa uniaxial cold pressing. Typically $\mathrm{ZrO}_{2}, \mathrm{Al}_{2} \mathrm{O}_{3}$ and $\mathrm{Al}_{2} \mathrm{O}_{3}-\mathrm{ZrO}_{2}$ composite when sintered at $1300-1650^{\circ} \mathrm{C}$ for $4 \mathrm{~h}$ achieved $\simeq 99 \%$ theoretical density. The scanning electron
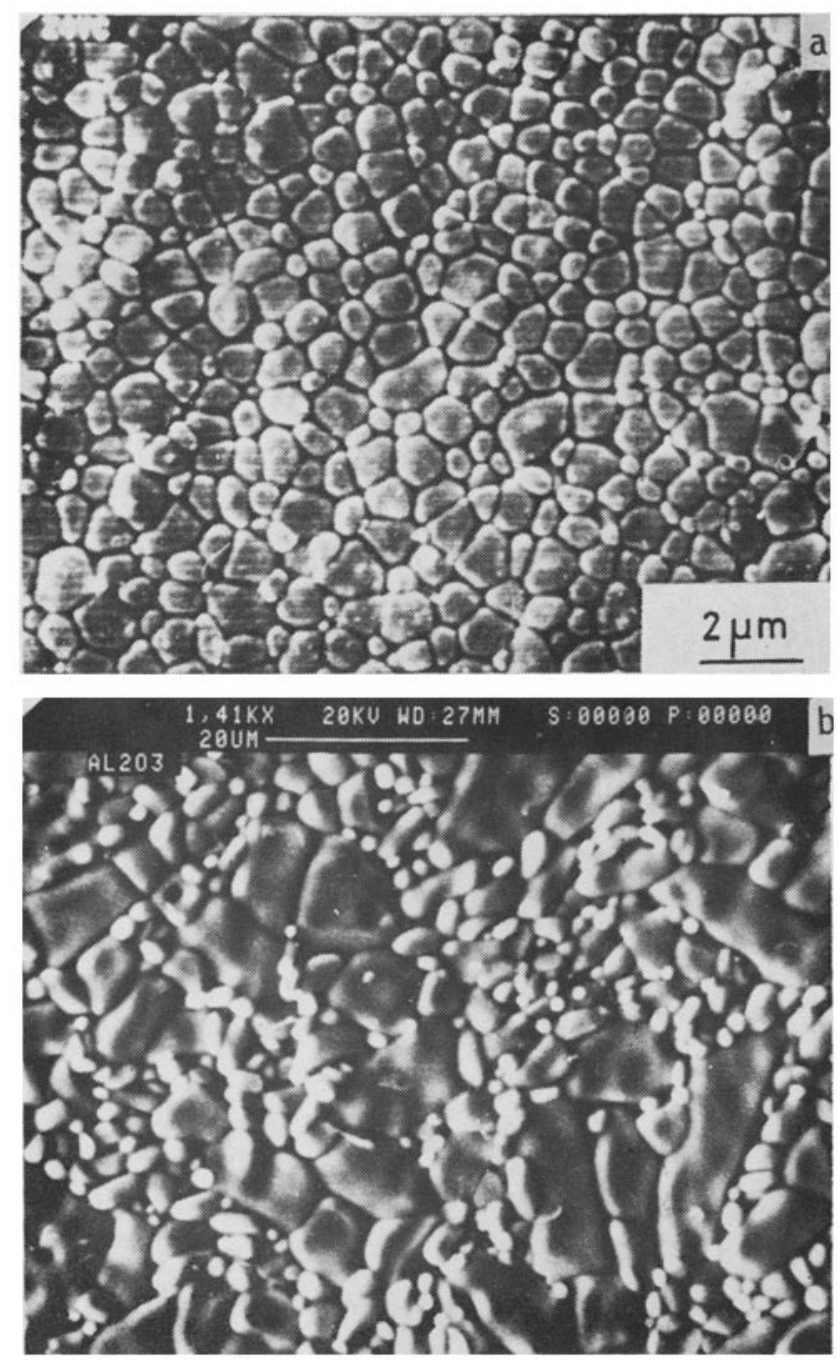

Figure 1a-b. 

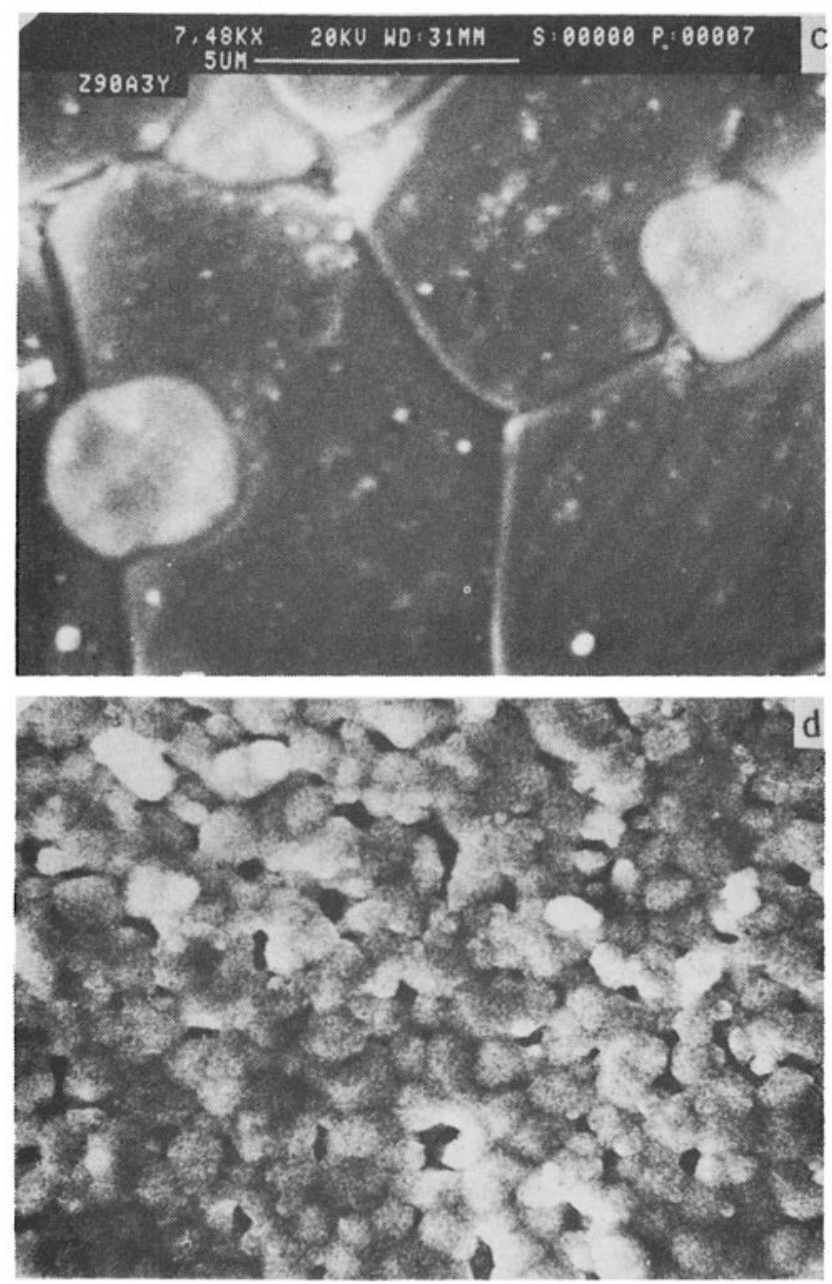

Figure 1. SEM micrographs of the surfaces of sintered pellets: (a) $\mathrm{ZrO}_{2}\left(1250^{\circ} \mathrm{C}, 4 \mathrm{~h}\right)$, (b) $\mathrm{Al}_{2} \mathrm{O}_{3}\left(1650^{\circ} \mathrm{C}, 4 \mathrm{~h}\right),(\mathrm{c}) \mathrm{Al}_{2} \mathrm{O}_{3}-\mathrm{ZrO}_{2}$ composite $\left(1650^{\circ} \mathrm{C}, 4 \mathrm{~h}\right)$ and (d) $\mathrm{PZT}\left(1200^{\circ} \mathrm{C}, 1 \mathrm{~h}\right)$.

microscope (SEM) micrograph of sintered $\mathrm{Y}_{2} \mathrm{O}_{3}$ stabilized $\mathrm{ZrO}_{2}, \mathrm{Al}_{2} \mathrm{O}_{3}, \mathrm{Al}_{2} \mathrm{O}_{3}-\mathrm{ZrO}_{2}$ composite and PZT are shown in figure 1. The microstructure of $\mathrm{ZrO}_{2}$ with $4 \mathrm{~mol} \%$ $\mathrm{Y}_{2} \mathrm{O}_{3}$ (figure 1a) sintered at $1250^{\circ} \mathrm{C}$ reveals fine-grained microstructure and the grains are almost equiaxed with an average grain size of 1 to $3 \mu \mathrm{m}$. The microstructure of $\mathrm{Al}_{2} \mathrm{O}_{3}$ (figure $1 \mathrm{~b}$ ) sintered at $1650^{\circ} \mathrm{C}$ shows nearly pore-free nature and occasionally the presence of exaggerated grains is noticed. Exaggerated grain growth could be avoided by adding a small amount of impurities such as $\mathrm{MgO}, \mathrm{Y}_{2} \mathrm{O}_{3}, \mathrm{TiO}_{2}$ etc. Microstructure of $\mathrm{Al}_{2} \mathrm{O}_{3}$ with $10 \mathrm{wt} \% \mathrm{ZrO}_{2}$ composite (figure 1c) sintered at $1650^{\circ} \mathrm{C}$ shows alumina grains (black contrast) with linear grain boundaries and pore-free nature of the body. Zirconia grains (white contrast) are almost equiaxed with 1-2 $\mu \mathrm{m}$ 
Table 4. A comparison between solution combustion and Merzhanov's SHS.

\begin{tabular}{|c|c|}
\hline SHS & Solution combustion \\
\hline Gasless solid state (i.e. solid $\rightarrow$ solid) process & Gas-producing solution (i.e. solution $\rightarrow$ solid) process \\
\hline Heterogeneous & Homogeneous or heterogeneous \\
\hline Flame temperature $>2000^{\circ} \mathrm{C}$ & Flame temperature $\geqslant 1000^{\circ} \mathrm{C}$ \\
\hline $\begin{array}{l}\text { Self-propagating only if the adiabatic temperature } \\
(\mathrm{Tad}) \text { is }>1800^{\circ} \mathrm{C}\end{array}$ & $\begin{array}{l}\text { Self-propagating even when the flame temperature } \\
>900^{\circ} \mathrm{C}\end{array}$ \\
\hline $\begin{array}{l}\text { Powders could be sintered to high density by } \\
\text { simultaneous application of pressure }\end{array}$ & $\begin{array}{l}\text { Compacted and sintered to near theoretical density } \\
\text { at low temperatures }\end{array}$ \\
\hline Commercialized & Yet to be commercially exploited \\
\hline
\end{tabular}

size and occupy the grain boundaries of large alumina grains. Microstructure of PZT (figure 1d) also shows uniform grain growth with an average grain sizes of $2 \mu \mathrm{m}$.

\section{Conclusions}

The combustion process described here has several advantages over the other methods in terms of simplicity, cost effectiveness, energy saving, purity and homogeneity. The main differences between Merzhanov's SHS and the combustion process described here (solution combustion) are given in table 4.

\section{References}

Arul Dhas N and Patil K C 1992 Int. J. SHS 1576

Arul Dhas N and Patil K C 1993a J. Solid State Chem. 102440

Arul Dhas N and Patil K C 1993b J. Mater. Chem. (in press)

Arul Dhas N and Patil K C 1993c Ceram. Int. (in press)

Carlson O N 1973 in Progress in extractive metallurgy (ed.) F Haboshi (New York: Gordon and Breach) Vol. 1 p. 189

Goldschmidt H 1898 Liebigs Ann. Chem. 30118

Gopichandran R and Patil K C 1990 Mater. Lett. 10291

Gopichandran R and Patil K C 1992a Mater. Lett. 12437

Gopichandran R and Patil K C 1992b Mater. Res. Bull. 27147

Gopichandran R and Patil K C $1993 \mathrm{Br}$. Ceram. Trans. (in press)

Jain S R, Adiga K C and Pai Verneker V 1981 Combust. Flame 4071

Kingsley J J, Manikam N and Patil K C 1990a Bull. Mater. Sci. 13179

Kingsley J J, Suresh K and Patil K C 1990b J. Mater. Sci. 251305

Kingsley J J, Suresh K and Patil K C 1990c J. Solid State Chem. 88435

Kingsley J J and Patil K C 1988 Mater. Lett. 6427

Kingsley J J and Patil K C 1990d Ceram. Trans. 12217

Mahesh G V, Ravindranathan P and Patil K C 1986 Proc. Indian Acad. Sci. (Chem. Sci.) 97117

Manoharan S S, Kumar N R S and Patil K C 1990 Mater. Res. Bull. 25731

Manoharan S S and Patil K C 1989 in Advances in ferrites (eds) C M Srivastava and M J Patni (New Delhi: Oxford and IBH) vol. 1, p. 43

Manoharan S S and Patil KC 1992a J. Am. Ceram. Soc. 751012

Manoharan S S and Patil K C 1993 J. Solid State Chem. 102267

Manoharan S S, Prasad K, Subramanium S V and Patil K C 1992b Physica C190 225

Merzhanov A G 1993 in Chemistry of advanced materials (ed.) C N R Rao (Oxford: Blackwell Scientific) p. 19

Patil K C 1986 Proc. Indian Acad. Sci. (Chem. Sci.) 96459

Patil K C 1991 Contributions to the chemistry of hydrazine derivatives and finite oxide materials, D. Sc.

Thesis, Indian Institute of Science, Bangalore 
Ravindranathan P and Patil K C 1986 J. Mater. Sci. Lett. 5221

Ravindranathan P, Mahesh G V and Patil K C 1987a J. Solid State Chem. 6620

Ravindranathan P and Patil K C 1987b Ceram. Bull. 66688

Ravindranathan P and Patil K C 1987c J. Mater. Sci. 223261

Segal D 1989 Chemical synthesis of advanced ceramic materials (Cambridge: University Press)

Sekar M A, Manoharan S S and Patil K C 1990 J. Mater. Sci. Lett. 91205

Sekar M A and Patil K C 1992a J. Mater. Chem. 2749

Sekar M A, Dhanaraj G, Bhat H L and Patil K C 1992b J. Mater. Sci. Elect. Mat. 3237

Sekar M A and Patil K C 1993 Mater. Res. Bull. 28485

Suresh K, Mahesh G V and Patil K C 1989a J. Therm. Anal. 351137

Suresh K, Mahesh G V and Patil K C 1989b in Advances in ferrites (eds) C M Srivastava and M J Patni (New Delhi: Oxford and IBH) vol. 1, p. 103

Suresh K, Kumar N R S and Patil K C 1991 Adv. Mater. 30148

Suresh K and Patil K C 1992 J. Solid State Chem. 9912

Suresh K and Patil K C 1993 J. Mater. Sci. Lett. 12572

Walton J D and Poulos N E 1959 J. Am. Ceram. Soc. 4240 